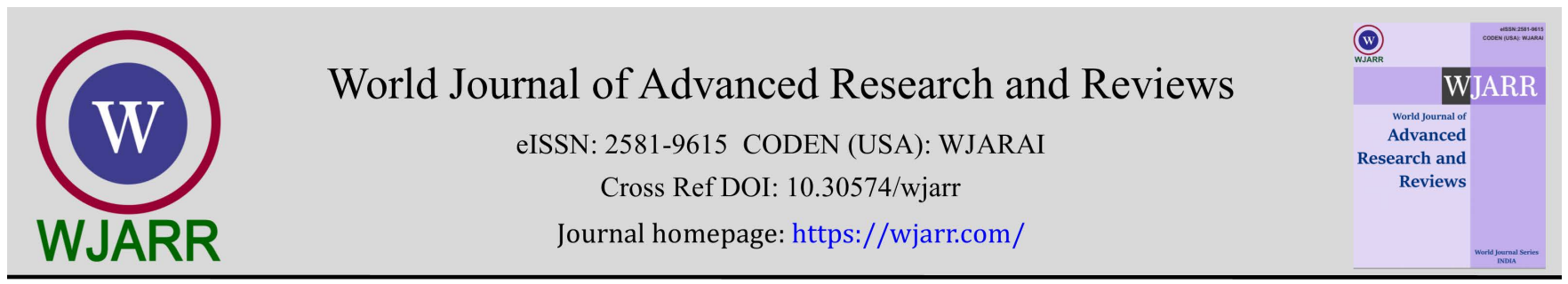

(REVIEW ARTICLE)

\title{
Transition to motherhood after egg donation and natural conception
}

\author{
Antonia-Aglaia Grylli and Antigoni Sarantaki * \\ Department of Midwifery, Faculty of Health \& Care Sciences, University of West Attica, Egaleo, Athens, 12243, GREECE.
}

World Journal of Advanced Research and Reviews, 2022, 13(02), 142-152

Publication history: Received on 30 December 2021; revised on 03 February 2022; accepted on 05 February 2022

Article DOI: https://doi.org/10.30574/wjarr.2022.13.2.0124

\begin{abstract}
Childbearing, has been recognized in the literature as a major life event that can invoke many challenges for the woman and her family. Motherhood, either by natural conception (NC) or by egg donation (ED), entails risks as mothers' psychological health is at high risk, during this crucial period. This systematic review was written with an eye to understand and explore the experience of motherhood between mothers lacking \& not, a genetic bond to their embryo. This systematic review was conducted, from June 2021 till November 2021. It encompasses researches with English as a written language, published during the period 2001-2021 and deposited in the UK. Online databases like PubMed \& Research Gate were used as a found and the selection criteria were, researches analyzing family building with oocyte donation or surrogacy in heterosexual couples. Adaption and embryo donation were inserted in the exclusion criteria. Ten studies were finally selected and fulfill all inclusion \& exclusion criteria of this systematic review. In each age group of children, differences, but also, similarities occurred between ED and NC mothers. Differences were referred mainly to mothers' psychological adjustment and mother-child interactions. After collating the final 10 studies, it was deduced that the experience of motherhood is almost close for each type of mother (ED or NC-IVF), with ED mothers, usually, face some extra thoughts and feelings towards the child and motherhood in general. Further research is suggested on mothers' experiences and attitudes after ED, as for now, researches are limited.
\end{abstract}

Keywords: Egg Donation; Surrogacy; Infertility; ART; Oocyte donation; Family building; Natural conception

\section{Introduction}

Assisted reproductive technology (ART) includes 'all fertility treatments, in which either eggs or embryos are handled outside a woman's body [1]'. A very important treatment modality concerning ART, is IVF (In Vitro Fertilization), where the 'egg or sperm are fertilized in a Petri dish [2]'. Looking back, interest in IVF methods, was already appreciable in the 1890s, when the first known attempt of embryo transplantation was carried out in rabbits [3].

ART procedures developed, in the first place, to treat infertility, 'a disease of the male or female reproductive system, defined by the failure to achieve a pregnancy after 12 months or more of regular unprotected sexual intercourse [4]'. In the Kahoun papyrus of ancient Egyptians, (dated 2200-1950 B.C.) infertility was explained as 'a disruption in the continuity between the reproductive organs and the digestive tract.' This result came from some common symptoms different women had experienced and after physical examination. Thus, it is not curious that, before the 1890s, people were troubled by the idea of infertility and have been looking for an explanation, considering the lack of knowledge and technology, to understand and answer the cause of the infertility problem [5].

With the world's first IVF baby dates back, as early as 1978 [3], until now, we have witnessed an increasing rise of interest moving towards to assisted conception services. Nevertheless, the technique of ART, that this systematic review concentrates upon, is Egg Donation (ED), namely when a donor egg is used [2] and so, the resulting offspring is only

\footnotetext{
${ }^{*}$ Corresponding author: Antigoni Sarantaki

Department of Midwifery, Faculty of Health \& Care Sciences, University of West Attica, Egaleo, Athens, 12243, GREECE.

Copyright (C) 2022 Author(s) retain the copyright of this article. This article is published under the terms of the Creative Commons Attribution Liscense 4.0.
} 
genetically attached to the father. ED was a technique ahead of its time that emerged in 1983, when the first woman with bilateral oophorectomy successfully impregnated, by using donor oocytes, in Australia [5].

Despite egg donation probability, in its early years, finding a donor egg was a not easy. Determinant was the apparition of egg banks and egg freezing. Oocyte banks made it possible for women to freeze their eggs, for future use, and therefore, became a great source of donor oocytes [6]. Since then, ED has increasingly advanced internationally, thanks to continuity in technology, and has gained more and more acceptance by society over the years. In the UK, usage of ED in IVF cycles was over 4,000 in 2017 [7], as well as, about 12\% of all IVF cycles occurred, by deploying eggs or sperm donation in 2018 (HEFA). According to the CMART report (2016) only 25 countries were using IVF in 1991, contrary to, 2016 when we discern a significant boost, in a total of 78 countries [8].

Simultaneously, surrogacy, an offshoot of ED, is widely known, and as well progressively preferable, when comes to family building nowadays. In particular, to outline, what surrogacy stands for, it is purposive to abstract genetic or traditional surrogacy from gestational or host surrogacy. Traditional or genetic surrogacy refers to another woman, a surrogate, who uses her oocytes, impregnated, usually, by the prospective father, gestates the baby until term, and relinquishes her parental rights and her genetically relative offspring to the intended couple, commonly, for a certain cost [9]. In the Bible, we see the very first third-party reproduction reference when Sarah, a woman confronted with infertility, appeal to Hagar, her maidservant, to gestate her husband's Abraham son [10].

Conversely, host or gestational surrogacy, which became increasingly popular, in the latter part of the 1990s, alludes to a surrogate uses her womb, as a host to an embryo, created with the oocytes of another woman and so an embryo not genetically connected with her. It deserves to be mentioned, the 'Baby M case', which took place in 1986, and became widely known as the first US court ruling on the legitimacy of surrogacy [11].

This constant pursuit of parenthood through ED, Surrogacy, or other ART techniques, indicates, the importance and necessity of parenting for human beings. Offspring's subsistence and welfare, have chiefly been depended on, by their parents, as we can see, throughout the ages. The parental care motivational system justifies parents' urge for caregiving and parenting. It may, also, be a stand for emotions like empathy, commiseration, and altruistic behaviors. To delineate, at length, the care motivation system, bears upon, humans' inclination to protect the vulnerable [12].

In particular, the transition to parenthood is associated with several hormonal modifications, such as shifts in oxytocin and testosterone [12], and can entail parts of development, including anxiety about becoming a parent. Equally, parents are at high risk of depression, during the first postnatal year. Parental postnatal psychological health is crucial to positive family functioning. Specifically, parents of the families, which are created through Assisted Reproductive Technologies (ARTs), are facing more assertive concerns and feelings. The individuals, who are experiencing parenthood, employing ARTs, have also been traversing, a period of infertility treatment, which tends to cause more stress to them. Even though all new parents are called, to accept a new reality, full of challenges, as they enter parenthood, but for those, who have interfered with egg donation, this transition might become a more complicated situation. The absence of genetic relation, between mother and children as also the older age of ED mothers, have been the main concerns [7]. Thus, as it is the center of this study, their experience through motherhood is the one that interests and, at the same time, fascinates the authors the most.

Women, commonly, are the primary caretakers. Being a mother, is not only a woman who gestates until term a baby, but also a woman who breeds and socializes [13]. As it has explained, there is more than one route that leads, to the path of motherhood, a path filled with physical and psychological impediments. Notwithstanding that, the challenges remain the same, whichever route a woman chooses to follow, either for genetically or non-genetically connected mothers. "The transition to motherhood is a major developmental life event. Becoming a mother involves moving from a known, current reality to an unknown, new reality" as Mercer supported [14]. Trying to adjust to that new reality, women, usually, adopt various strategies, such as 'recognizing the permanency of the required change, seeking information for construction of a new self-definition, seeking models for a new normalization, and competency testing of self in the new role' [14]. Nelson (2003), equally, predicated that "Engagement is the basic social process in maternal transition, which enables the often-simultaneous process of growth and transformation" [15]. Experiencing the preliminary stages of transition to motherhood, however, may not be, a privilege for women who choose ED through surrogacy. For each woman, although, this rite of passage may be influenced by her beliefs, her personal condition, environment, socioeconomic status (SES), preparation, awareness, community, and societal state.

This systematic review aims to bring into focus, the transition to parenthood of the genetic related mother, in comparison with, the angle of the non-genetically connected to the embryo mother. Moreover, it is crucial to be 
examined, the psychological health of the mothers that were facing fertility issues, and finally, are calling to be entered into parenthood.

\section{Methods}

\subsection{Literature search strategy}

For this systematic review, medical and psychological online databases were leveraged, in the second half of 2021 and more specifically from June 2021 till November 2021, through PubMed, ScienceDirect, SpringerLink, Research Gate, and National Library of Greece to obtain studies focused on the transition to motherhood, on the families which were created through the mechanism of egg donation, and the genetically related families. The search terms that were used, were, basically, egg donation, parent-child relationship, motherhood, transition to motherhood, oocyte donation, egg donation, surrogacy, family building, and parenting. To collect general information about the procedure of egg donation, the terms of IVF, infertility, and Assisted Reproductive Methods have been searched.

\subsection{Inclusion and exclusion criteria}

In this systematic review, articles written in English have been accepted. Only qualitative papers were included, and systematic and bibliographic reviews were rejected. The search was initiated from 2001 to 2021 with United Kingdom as a restriction set for study location. The basic inclusion criterion was the participants of the study, which had to be, only, heterosexual couples. In the inclusion criteria were also families created through the process of oocyte donation or surrogacy (genetic), thus, families after adaption or embryo donation were excluded. In each study a comparison has to been made between mothers genetically connected and not to their child in order to be able to come to a conclusion after a reliable comparison. Moreover, the vast majority of the researchers were using as samples the relation between the mother and the children, which were divided into stages. In this systematic review, only the stages that are referring to children between neonatal up to school age have been concluded.

\subsection{Findings of the review}

This search has, originally, involved 86 studies (Table 1). Of those, 12 were systematic reviews and excluded at a stretch. Approximately, 21 studies were precluded, because of their title irrelevance. After that, 53 studies remained, for further evaluation. Another 43 studies were excluded after analysis of the abstract or the entire study and did not match the selection criteria of this review. Eventually, 10 studies met the inclusion criteria and were selected for this review.

\subsection{Quality assessment of the reviewed papers- Research strategy}

Differences, between, how women experiencing motherhood, as a result of, egg donation (not genetically connected with the infant), in opposition to, mothers with a genetic bond with their child, are the primary animus of this systematic review of the literature. Research, get started on June 2021 under, a very distinctive bout, the COVID-19 pandemic. PRISMA criteria (Preferred Reporting Items for Systematic Reviews and Metanalyses) were used to guide the search process [16]. The final ten articles were perused and then analyzed, at length, to verify that they fulfill all the inclusion and exclusion criteria. PUBMED, Science direct, and Research Gate databases have been used as a fount. Advanced Search Builder, on the PUBMED database, was used as an asset for our keywords [Title OR Abstract]. Precise filters have been used, such as date of publication, constrained at 2001-2021, the language of writing, as only English was accepted, and finally full-text access to the article.

\section{Results}

\subsection{Description of included studies}

After a thorough search, followed by an attentive analysis, the final ten studies have been selected. The United Kingdom was the hotspot with all 10 studies situated there. All final studies examine only families consisted of heterosexual couples, with most of them, claimed, being married or cohabiting. As the main focus was, to understand and compare motherhood with and without a genetic bond to the embryo, mostly studies that pertain to families created through the process of Egg Donation, Surrogacy (genetic), and families formed by natural conception or IVF techniques that mothers' own gametes were used, have been chosen.

Referring to the samples, most studies contain women with a wide age range as mothers through NC, who seem to experience parenthood younger, in contrast to, the ED or mothers after surrogacy. Thus, the mother's age, history of IVF cycles, the number of siblings, and social class, who appeal to differ in each family type, have been included in each study 
as covariates. MANOVA (Multivariate Analysis of Variance) and in extension ANOVA (Analysis of Variance) procedures have been used by researchers in many of the final studies to analyze these covariates. Children's age, similarly, differs among studies, with three studies assessing women when the child was 6-18 months old, while others, when the child was $1,2,3,7$, and - or 10 . Also, inclusion criteria were used by many studies for NC families like planned pregnancy with a minimum of 30 weeks gestation, singleton birth with no congenital abnormalities, mother at least 30 years old married or cohabiting with baby's father and the baby had to be the mothers' first or second child.

The vast majority of the researches were based on recording the parental bond, without disaggregating and focusing on the mother's side. The families were studied as an entirety. Since, the main focus of this systematic review is to examine the transition to motherhood, specifically, the parts that referred only to the mother's part have been selected, and correspondingly, the elements that are alluded to the father's side, have been excluded. Also, there is no limitation about the mothers who are employed outside or inside the home, full-time or part-time employed, or not employed at all. Furthermore, it is crucial to mention that the majority of the researches were conducted through questionnaires and interviews (tape-recorded interviews) or observational tasks (video recorded) with the researchers being visited the family at home. Commonly mothers and fathers were those who participate in the research but in two of the final studies, however, the teacher of the child participated too by filling a questionnaire. In one study, likewise, the children were the basic participants.

The same procedures were used, by the majority of the studies, to measure the mother's psychological adjustment and the mother-child relationship. The parent's level of depression was appraised most of the time by the Edinburgh Depression Scale and level of anxiety by both the Vulnerable Child Scale and the Trait Anxiety Inventory as well. The Parenting Stress Index (PSI) was used to assess parenting stress and the Golombok Rust Inventory of Marital Scale (GRIMS) for the marital relationship between the couple. As to evaluate the mother-child relationship, Parent Development Interview (PDI) and the Attachment Questionnaire were used. In one study through the McArthur Story Stem Battery and the Family Maps revealed the quality of the relationship between mother and child from the child's perspective. For the representation measure and perceived social support, the Parent Development Interview and the Multidimensional Scale of Social Support were used respectively. Furthermore, quality of parenting and child psychological adjustment deemed as necessary to be defined. Both Strengths and Difficulties Questionnaire (SDQ) and the Brief Infant Toddler Social and Emotional Assessment (BIT-SEA), have been utilized by researchers for the needs of children's adjustment measurement. Maternal positivity, negativity, and distress levels in some studies resulted from the Confirmatory Factor Analysis using Mplus in mother's data. Observational measures were gained as well.

\subsection{Results of the psychological adjustment between mothers with genetic relation and E.D. mothers.}

As our research concerns and includes various age ranges of children, it is crucial to consider the results of each age group separately. Research results about ED mothers and their transition to motherhood are mentioned analytically as detailed below. Further comparisons between them and mothers with a genetic link to the embryo will be made later on in our study.

Two of the final researches' participants were ED mothers and IVF mothers (with a genetic bond to the infant) of 6-18 months old infants. In one of them ED mothers seem to be psychologically well adjusted [7] while in the other one, some differences can be descried. More specifically, a lower level of interaction between mother and child, lower confidence in parenting, and less sensitivity have been noticed in ED in contrast to IVF mothers [17].

When the children were 1,7 and 10-years-old lower levels of parental stress and depression were appealed to the ED mothers', who intended or have already started the process of disclosure $[18,19]$. No significant differences were found for ED mothers of 2-years-old children for psychological well-being [18], anxiety, depression, or marital satisfaction [20]. Although, many positive representations for the mother-child relationship and maternal feelings occurred for the egg donation families [20,21]. More specifically, as for maternal experience, differences occurred between ED and NC families. Lower levels of anger, guilt, and disappointment in contrast to higher levels of joy/pleasure and competence obtained among surrogacy families in opposition to NC families. As concerns the child's point of view, the levels of child aggression were lower in surrogacy families and the degree of child affection was at a higher level in surrogacy than both in ED and NC family type [21].

Psychological well-being as concerns the intention for disclosure did not show any significant difference between family types at the age of 3 [18,22]. Mother-child relationships do not appeal to be affected by the absence of genetic-bond between them. Contrarily, higher levels of joy, warmth, and interaction were reflected between mothers and their 3 years old child as compared with the NC mothers [22]. Generally, the quality of parenting at the age of 7 and 10 seems not to be influenced by egg donation [19], and ED mothers' attitudes were reflected high in warmth and involvement 
[22]. However, it appears that NC children reported sharing fewer activities and interests at age 10 as at age 7, while in ED families this decrease was not found [22]. More important for children seems to be the absence of a gestational than a genetic relationship between mother and child according to one study that showed lower levels of adjustment problems in ED children beside children born through surrogacy [19]. On the contrary, in one of ten studies, maternal caretaking absents from the stories of ED children in contrary to NC children [22] and in another one mother-child relationships at age 7 were found to be less positive in ED families [21].

\section{Discussion}

The aim of this systematic review, was to understand the experience of becoming a mother through the ED process and how difficulties of this transition differ between two groups, mothers with a genetic link to the embryo (through NC or IVF) and mothers with the absence of that link.

Becoming a mother, as a life change event, regardless of the procedure, affects women in many ways. Feelings like insecurity, fear, high responsibility, anxiety, distress, worry, or even depression are normal to appear, as motherhood, even more as a first-time experience, is an unknown path with no written directions. Generally, women may feel like they are not ready or totally unprepared for parenthood or may not believe to have that mother material. As the NC or IVF thus the ED or surrogacy mothers seem to share the same concerns and fears but they also appeal to differ in their adjustment to motherhood. Researches that study the comparison between those two types of mothers are not many, and transition to motherhood after ED needs further discussion.

Initially, to compare the transition to motherhood at its very first steps, two of the final ten studies have been used, with participants, mothers of infants at the first 6-8months of their life [7,17]. The participants of both studies were ED mothers compared to IVF mothers (genetic link to the infant) $[7,18]$. One of the two studies indicate that both types of mothers were within the normal range of parenting stress and postnatal depression and both were appeared psychologically well-adjusted [7]. On the other hand, the second study indicates very few differences between IVF and ED mothers. Those differences were mostly about mother-infant relationship quality. According to the observational assessment the interaction quality, sensitivity, and structuring were found to be less optimum or poorer in ED mothers compared to IVF mothers. A lack of confidence as concerns the parenting ability has been the main difference between ED and IVF mothers, with ED require more [17].

Even so the two studies accord to each other that both types of mothers viewed themselves as high in warmth, joy, and pleasure, satisfactory to high in child focus and capability, and, at the same time, low in disappointment and anger. Moreover, both of them showed low levels of boredom or disconnect with their children. Both mother types were found to share more and differ less. An assumption may be that their similarities result from their common drive, need and effort to become parents with the help of ART services. Commonly, parents of families that were formed through ART procedures seem to be more dedicated and affectionate as they handle their children like something very rare and valuable. The lower level of confidence may be at the one hand in consequence of the older age but at the other hand may be disquietly leading to the lack of genetic connection between the mother and the infant. Considering that mothers after IVF and ED procedure, normally, do not have such a big age divergence, compares to NC mothers, who seem to have the fewest mean age. Thus, it stands to reason that the absence of a genetic link reflects a lower level of mother assurance.

In order to follow the transition of the infant to toddler, six studies that analyze the transition to motherhood when the children were 1, 2 and-or 3 years old have been used [18-21,23,24]. Similarities are also significant but in this age range, it seems that more differences have been occurred in contrast to the previously referred researches. Four out of six chosen studies compare mothers after natural conception with ED or surrogacy mothers and only one ED mothers with DI mothers.

Almost all of the studies conclude that NC and ED mothers were psychologically well-adjusted and within the normal ranges for postnatal depression and anxiety [7, 18,21,25]. Only one study indicates that surrogacy mothers scored lower levels of anxiety and depression than NC and ED mothers. Nevertheless, one other study annotates a determinant factor that renders ED and surrogacy mothers more susceptible to higher levels of anxiety, depression, and stress, in contrast to, genetically related to their child mothers, and this is disclosure. Disclosure is connected to the decision or not to open up to your child about his genetic origin and the way he conceived. When the children were 1-year old, lower levels of parental stress and depression occurred in the mothers who have decided or even started to talk to their children about their origins $[18,19]$. 
At the age of 2-years-old children, there were no differences found between family types as concerns the parental stress and disclosure. Contrarily, mothers with a genetic link to the embryo do not have such a decision to make. The fear for disclosure is a foregone conclusion as it stands to reason, mothers may believe that after disclosure the lack of a genetic bond may affect the mother-child relationship and child feelings towards her. By the majority of the studies, the lack of a genetic bond does not seem to be problematic for the mother-child relationship or children's closeness to their mother, conversely, it seems to bring closer and ameliorate their relationship [20,21,25]. More specifically, at the age of 2, the absence of a genetic connection to the child results in more positive feelings of the mother towards it and accretes the mother's belief about the child's uniqueness and vulnerability [25] as well as at the age of 3-year-old children, that ED mother-child relationship described as higher in warmth contrary to NC families [24]. This is a logical outcome if we assume that mothers after gamete donation experience parenthood as a gift and their child as something very vulnerable and extremely wanted. They are more determinant, dedicated, loving, and affectionate mothers. Parents who choose to undergo IVF procedures seem to have a true and deep desire to have children and experience parenthood.

Generally, NC and ED children did not differ substantially in their adjustment. Only, when it comes to disclosure their differences become more visible. At the age of 3 years old children, one study indicates that lack of genetic bond between mother and child does not affect the child as much as the lack of gestational connection. In other words, children seem to have trouble with the thought that their mother did not carry and deliver those [19]. Moreover, 3-year-old children of the mothers who were distressed and were not informed yet about their biological origin seem to have more significant adjustment difficulties in opposition to NC children. NC and ED children, all in all, appear to have almost equal chances to develop some kind of adjustment problem.

The differences found among the studies were mostly about parenting. As for joy/pleasure, in particular, ED and surrogacy mothers seem to hold higher levels in contrast to the group of NC mothers. All mothers' emotions seem to be high in warmth, enjoyment, affection, and involvement and low in hostility (antagonism - unfriendliness), disappointment, and anger against the child [17]. In one study, surrogacy mothers showed even lower levels of depression and parenting stress and greater acceptance than the comparison group of NC families [25]. Sometimes, though, higher levels of enjoyment and appreciation co-occur with higher levels of concern by the parents for the child's well-being and parents become overprotected and emotional overinvolvement.

At the age of 2-years-old children two studies shown greater representations for mother-child relationships in contrast to NC families [20,21]. As for marital satisfaction, there were no significant differences occurred between the two comparison groups.

When it comes to the last age group of children, ED and NC families with $7-10$ years old children have been chosen for evaluation. At the age of 7 years, old parenting stress and depression levels seem to be associated with mothers' decision for disclosure or not. Lower levels of depression and anxiety have been observed in mothers that have started the process or even have already talked to their children about their origins. Mother-child interactions were poorer when 7 years old children were not informed [25]. Contrarily, at the age of 10 years old, there were no significant differences observed between the two compared mother types about disclosure [18]. Generally, children from both family types' levels of adjustment were close. One of the studies indicates that more adjustment problems are noticed in children who have been aware of their birth procedure and mothers with high levels of depression related to the "fear" of disclosure [19]. At the age of 7-and 10-years old children, likewise the age of 3, gestation concerns more children than conception. The absence of genetic connection between mother and child did not appear to influence their relationship.

According to the majority of the studies in this systematic review, mother and child connection were described as high in warmth, enjoyment, and involvement in both NC and ED-surrogacy families when the children were 7 or 10 years old $[18,25]$. Maternal positivity and negativity, also, was not much alike between those two comparison groups. We deduce that by the age of 7- and 10-years old children and their mothers have reconciled themselves with the idea of egg donation and non-genetic connection between them and learn to love and feel each other as a family regardless that. This is, maybe, why there were no important differences found between none and genetically related family types. Another study has shown that at the age of 7, NC children described sharing fewer common interests and activities with their mother as ED children. ${ }^{25}$ this may be relative to the consecutive "fear" of mothers after gamete donation of the genetic bond absence with the child. Mother's insecurity makes them try harder and harder and give the best possible of themselves to their child as to the belief that they have to fill a bigger gap to become mothers as also in the motherchild relationship in contrast to genetically related ones. Another explanation may derive from something that we mentioned above, that parenthood by natural conception sometimes results by accident in contrast to ART conception that is almost all the times deeply wanted. 


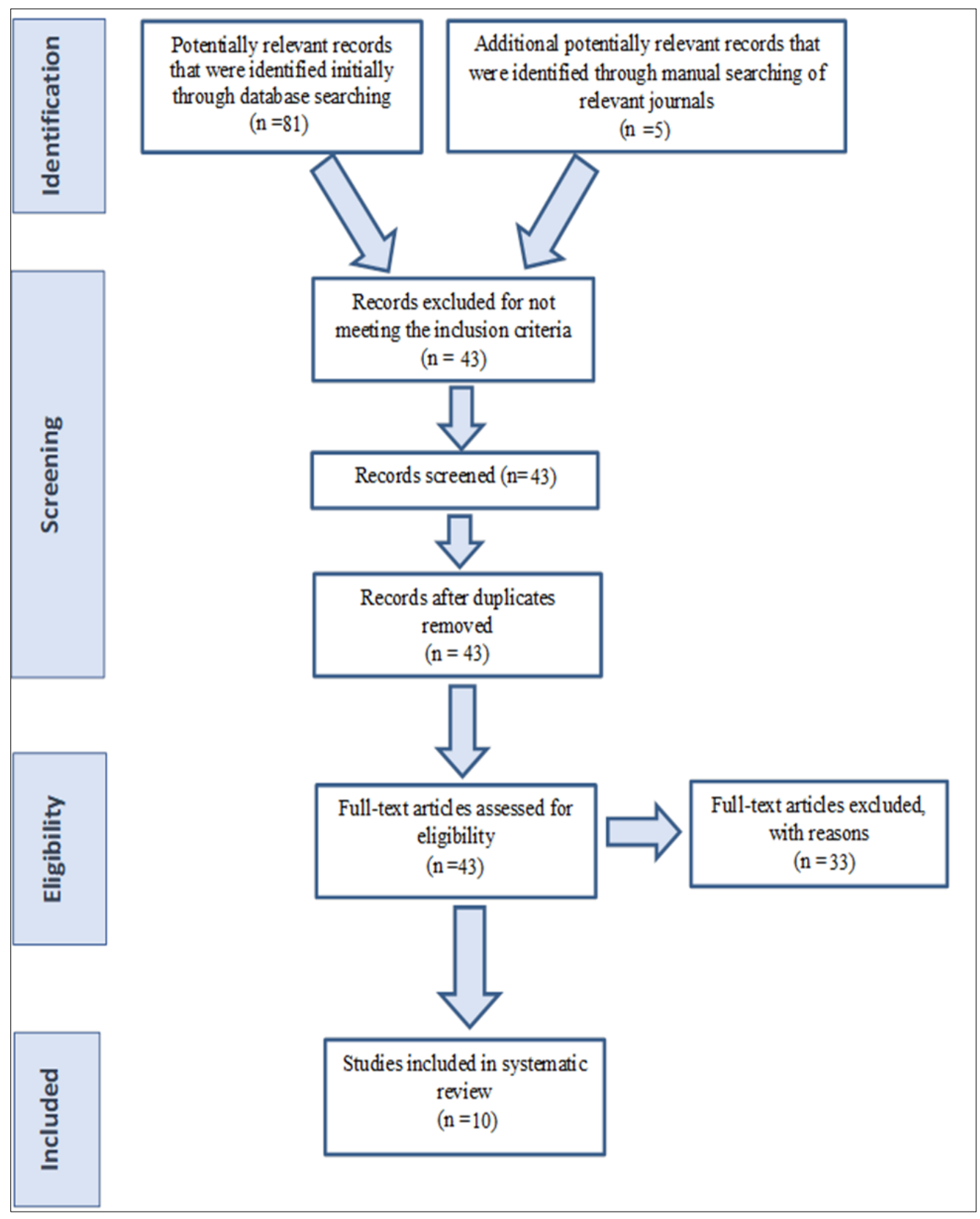

Figure 1. Flow chart describing the selection of articles

Table 1 Characteristics of the included studies

\begin{tabular}{|c|c|c|c|c|c|c|}
\hline $\begin{array}{c}\text { Authors, } \\
\text { Year }\end{array}$ & Country & $\begin{array}{l}\text { Study } \\
\text { Design }\end{array}$ & $\begin{array}{l}\text { Sample Size, } \\
\text { Comparison }\end{array}$ & Research Tools & Results & Conclusion \\
\hline $\begin{array}{l}\text { Blake L, Jadva } \\
\text { V, and } \\
\text { Golombok S. } \\
(2014)\end{array}$ & $\begin{array}{l}\text { United } \\
\text { Kingdom }\end{array}$ & $\begin{array}{l}\text { Quantitative } \\
+ \text { Qualitative } \\
\text { study }\end{array}$ & $\begin{array}{l}34 \text { DI families, } \\
30 \text { ED families }\end{array}$ & $\begin{array}{l}\text { Standardized } \\
\text { Questionnaires (mother\& } \\
\text { teacher) } \\
\text { \& Interviews(mother) }\end{array}$ & $\begin{array}{l}\text { At the age of } 1,7 \text { and } 10 \\
\text { years old both levels of } \\
\text { depression and anxiety } \\
\text { were lowest for mothers } \\
\text { who planned to tell their } \\
\text { child about their origin. }\end{array}$ & $\begin{array}{l}\text { Greater levels of } \\
\text { psychological } \\
\text { adjustment were found } \\
\text { for mothers who } \\
\text { planned to tell their } \\
\text { child about the nature of } \\
\text { their origin. }\end{array}$ \\
\hline
\end{tabular}




\begin{tabular}{|c|c|c|c|c|c|c|}
\hline $\begin{array}{l}\text { Golombok S, } \\
\text { Blake L, Casey } \\
\text { P, Roman G, } \\
\text { and Jadva V } \\
\text { (2013) }\end{array}$ & $\begin{array}{l}\text { United } \\
\text { Kingdom }\end{array}$ & $\begin{array}{l}\text { Quantitative } \\
+ \text { Qualitative } \\
\text { study }\end{array}$ & $\begin{array}{ll}30 & \text { surrogacy } \\
\text { families,31 ED } & \text { families,35 } \quad \text { DI } \\
\text { families and } 53 \\
\text { NC families. }\end{array}$ & $\begin{array}{l}\text { Standardized } \\
\text { Questionnaires } \\
\text { \& Interviews (mother \& } \\
\text { father) }\end{array}$ & $\begin{array}{lr}\text { An overall } & \text { difference } \\
\text { occurred for } & \text { Maternal } \\
\text { distress, } & \text { children } \\
\text { adjustment } & \text { and } \\
\text { parenting for } & \text { non- } \\
\text { disclosure families }\end{array}$ & $\begin{array}{l}\text { The absence of } \\
\text { gestational connection } \\
\text { to the mother may be } \\
\text { problematic for the } \\
\text { children than the } \\
\text { absence of genetic link }\end{array}$ \\
\hline $\begin{array}{l}\text { Imrie S, Jadva } \\
\text { V, Golombok S, } \\
\text { Fishel S } \\
\text { (2019) }\end{array}$ & $\begin{array}{l}\text { United } \\
\text { Kingdom }\end{array}$ & $\begin{array}{l}\text { Qualitative } \\
\text { Study }\end{array}$ & $\begin{array}{l}85 \text { ED families } \\
\text { and } 65 \text { IVF } \\
\text { families using } \\
\text { the parents' } \\
\text { own gametes }\end{array}$ & \begin{tabular}{|rr} 
video & recorded \\
observational & task and \\
audio & recorded \\
standardized & interview \\
(each parent) &
\end{tabular} & $\begin{array}{llr}\text { Differences } & \text { between } \\
\text { family types: } & \\
\text { 1)lower levels } & \text { of } \\
\text { confidence } & \text { among } & \text { ED } \\
\text { mothers than } & \text { IVF } \\
\text { mothers. } & & \\
\text { 2) less } & \text { optimal } \\
\text { sensitivity } & & \text { and } \\
\text { structuring } & \text { among } & \text { ED } \\
\text { mothers. } & & \end{array}$ & $\begin{array}{l}\text { 1) ED mothers showing } \\
\text { lower confidence in } \\
\text { their parenting ability } \\
\text { than IVF mothers } \\
\text { 2) ED mothers were less } \\
\text { optimally sensitive and } \\
\text { structuring than IVF } \\
\text { mothers, and ED infants } \\
\text { were less emotionally } \\
\text { responsive and } \\
\text { involving of the mother } \\
\text { than IVF infant. }\end{array}$ \\
\hline $\begin{array}{l}\text { Imrie S, Jadva } \\
\text { V and } \\
\text { Golombok S. } \\
\text { (2019) }\end{array}$ & $\begin{array}{l}\text { United } \\
\text { Kingdom }\end{array}$ & $\begin{array}{l}\text { Quantitative } \\
\text { Study }\end{array}$ & $\begin{array}{l}57 \text { ED families } \\
\text { and } 56 \text { IVF } \\
\text { families using } \\
\text { the parents' } \\
\text { own gametes }\end{array}$ & $\begin{array}{l}\text { standardized } \\
\text { Questionnaires (mother } \\
\text { \& father) }\end{array}$ & $\begin{array}{l}\text { Less optimal social } \\
\text { support to ED mothers } \\
\text { than IVF } \\
\text { mothers. } \\
\text { ED and IVF mothers did } \\
\text { not differ in their } \\
\text { psychological health. }\end{array}$ & $\begin{array}{l}\text { Mothers in ED and IVF } \\
\text { families were } \\
\text { psychologically well- } \\
\text { adjusted, with levels of } \\
\text { postnatal depression } \\
\text { and parenting stress } \\
\text { within the normal range. }\end{array}$ \\
\hline $\begin{array}{l}\text { Golombok S, } \\
\text { Readings J, } \\
\text { Blake L, Casey } \\
\text { P, Mellish L, } \\
\text { Marks A and } \\
\text { Jadva V. } \\
(2011)\end{array}$ & \begin{tabular}{|l} 
United \\
Kingdom
\end{tabular} & $\begin{array}{l}\text { Qualitative+ } \\
\text { Quantitative } \\
\text { Study }\end{array}$ & $\begin{array}{l}32 \text { ED families, } \\
36 \text { DI families } \\
\text { and } 54 \mathrm{NC} \\
\text { families. }\end{array}$ & $\begin{array}{l}\text { standardized interview } \\
\text { (mother \& teacher) and } \\
\text { Questionnaire Video } \\
\text { recorded observational } \\
\text { task(mother-child) }\end{array}$ & $\begin{array}{l}\text { Compared with natural } \\
\text { conception group, the } \\
\text { gamete donation not } \\
\text { informed group had a } \\
\text { significantly lower } \\
\text { completely } \\
\text { standardized mean of } \\
\text { both mother child } \\
\text { mutuality }\end{array}$ & $\begin{array}{l}\text { The gamete donation } \\
\text { informed group still had } \\
\text { a significantly lower } \\
\text { completely } \\
\text { standardized mean than } \\
\text { the NC for both mother- } \\
\text { child mutuality but not } \\
\text { for maternal positivity } \\
\text { and negativity. Mother- } \\
\text { child relationships were } \\
\text { found to be less positive } \\
\text { in GD families than in NC } \\
\text { families. }\end{array}$ \\
\hline $\begin{array}{l}\text { Golombok S, } \\
\text { Murray C, } \\
\text { Jadva V, Lycett } \\
\text { E, MacCallum F } \\
\text { and Rust.J } \\
\text { (2006) }\end{array}$ & \begin{tabular}{|l} 
United \\
Kingdom
\end{tabular} & $\begin{array}{l}\text { Quantitative } \\
\text { +Qualitative } \\
\text { Study. }\end{array}$ & $\begin{array}{l}34 \text { surrogacy } \\
\text { families,41 ED } \\
\text { families }, 41 \text { DI } \\
\text { families and } 67 \\
\text { NC families. }\end{array}$ & $\begin{array}{l}\text { tape-recorded } \\
\text { interview(mother) and } \\
\text { questionnaire (mother \& } \\
\text { father) }\end{array}$ & $\begin{array}{l}\text { 1)the surrogacy and ED } \\
\text { mothers were showing } \\
\text { higher levels of } \\
\text { interaction with their } \\
\text { child than the mothers } \\
\text { of DI. } \\
\text { 2)higher levels of } \\
\text { warmth and interaction } \\
\text { between mothers and } \\
\text { their 3-year-old } \\
\text { children in the assisted } \\
\text { reproduction families } \\
\text { than in NC families. }\end{array}$ & $\begin{array}{l}\text { 1)The absence of } \\
\text { genetic or gestational } \\
\text { link between the mother } \\
\text { and the child does not } \\
\text { appear to impact } \\
\text { negatively on parent- } \\
\text { child relationships. } \\
\text { 2) With respect to } \\
\text { psychological well- } \\
\text { being, no differences } \\
\text { were identified between } \\
\text { family types for either } \\
\text { parents or children }\end{array}$ \\
\hline $\begin{array}{lr}\text { Golombok } & \text { S, } \\
\text { MacCallum } & \text { F, } \\
\text { Murray } & \text { C, } \\
\text { Lycett E and } \\
\text { Jadva.V } \\
\text { (2006) }\end{array}$ & $\begin{array}{l}\text { United } \\
\text { Kingdom }\end{array}$ & $\begin{array}{l}\text { Quantitative } \\
\text { +Qualitative } \\
\text { study }\end{array}$ & $\begin{array}{l}37 \text { Surrogacy } \\
\text { families ,48 ED } \\
\text { families and } 68 \\
\text { NC families. }\end{array}$ & $\begin{array}{l}\text { Tape recorded interview } \\
\text { and questionnaire } \\
\text { (mother \& father } \\
\text { separately). } \\
\text { Bayley Scale(children) }\end{array}$ & $\begin{array}{l}\text { Surrogacy mothers } \\
\text { showed more positive } \\
\text { parent-child } \\
\text { relationships than their } \\
\text { natural conception } \\
\text { counterparts. }\end{array}$ & $\begin{array}{l}\text { Surrogacy does not } \\
\text { appear to impact } \\
\text { negatively on parenting } \\
\text { or child development in } \\
\text { families with 2-year-old } \\
\text { children. }\end{array}$ \\
\hline
\end{tabular}




\begin{tabular}{|c|c|c|c|c|c|c|}
\hline $\begin{array}{l}\text { Blake L, Casey } \\
\text { P, Jadva V, } \\
\text { Golombok.S } \\
(2014)\end{array}$ & $\begin{array}{l}\text { United } \\
\text { Kingdom }\end{array}$ & $\begin{array}{l}\text { Quantitative } \\
+ \text { Qualitative } \\
\text { study }\end{array}$ & $\begin{array}{lr}31 & \text { DI } \\
\text { families,28 } & \mathrm{ED} \\
\text { families and } & 51 \\
\mathrm{NC} \text { families } & \end{array}$ & $\begin{array}{l}\text { Children ( } 7 \& 10 \text { yrs old) } \\
\text { completed the MSSB } \\
\text { (only the } 7 \text { yrs old), a } \\
\text { family map and were } \\
\text { administered an } \\
\text { interview. The MSSB and } \\
\text { the interview were audio } \\
\text { recorded. Children at ED } \\
\text { and DI families in which } \\
\text { parents had disclosed } \\
\text { their use of donated } \\
\text { gametes to the child were } \\
\text { given an additional set of } \\
\text { questions focusing on the } \\
\text { donor conception. }\end{array}$ & $\begin{array}{l}\text { Maternal caretaking } \\
\text { was most common in } \\
\text { stories of DI and NC } \\
\text { children and least } \\
\text { common in ED children. } \\
\text { At the age of } 10 \text { children } \\
\text { in NC families reported } \\
\text { sharing fewer activities } \\
\text { and interests with their } \\
\text { mother than at age } 7 .\end{array}$ & $\begin{array}{l}\text { The absence of a genetic } \\
\text { link between one of the } \\
\text { parents and the child } \\
\text { did not appeal to effect } \\
\text { children's feelings of } \\
\text { closeness to their } \\
\text { parents. }\end{array}$ \\
\hline $\begin{array}{ll}\text { Golombok } & \text { S, } \\
\text { Murray } & \mathrm{C}, \\
\text { Jadva } & \text { V, } \\
\text { MacCallum } & \text { F, } \\
\text { Lycett E } & \\
(2004) & \end{array}$ & $\begin{array}{l}\text { United } \\
\text { Kingdom }\end{array}$ & $\begin{array}{l}\text { Quantitative } \\
\text { +Qualitative } \\
\text { study }\end{array}$ & $\begin{array}{l}42 \text { surrogacy } \\
\text { families ,51 ED } \\
\text { families and } 80 \\
\mathrm{NC} \text { families. }\end{array}$ & $\begin{array}{lr}\text { Mother \& Father } \\
\text { separately) } \\
\text { recorded interview and } \\
\text { questionnaire }\end{array}$ & $\begin{array}{l}\text { The surrogacy mothers } \\
\text { obtained significantly } \\
\text { lower scores for } \\
\text { parental distress than } \\
\text { both the NC and ED } \\
\text { mothers. }\end{array}$ & $\begin{array}{l}\text { higher level of warmth, } \\
\text { emotional } \\
\text { overinvolvement, } \\
\text { enjoyment and greater } \\
\text { acceptance among the } \\
\text { surrogacy mothers than } \\
\text { the NC mothers. }\end{array}$ \\
\hline $\begin{array}{l}\text { Golombok S, } \\
\text { Jadva V, Lycett } \\
\text { E, Murray C } \\
\text { and } \\
\text { MacCallum F } \\
\text { (2004) }\end{array}$ & $\begin{array}{l}\text { United } \\
\text { Kingdom }\end{array}$ & $\begin{array}{l}\text { Quantitative } \\
+ \text { Qualitative } \\
\text { study }\end{array}$ & $\begin{array}{lr}46 & \text { DI } \\
\text { families,48 } & \text { ED } \\
\text { families and } & 68 \\
\text { NC families } & \end{array}$ & $\begin{array}{l}\text { (Mothers \& Fathers } \\
\text { separately) Data were } \\
\text { obtained by tape- } \\
\text { recorded interview and } \\
\text { questionnaire. }\end{array}$ & $\begin{array}{l}\text { Gamete Donation } \\
\text { mothers showed a trend } \\
\text { towards greater } \\
\text { pleasure in their child } \\
\text { accompanied by a } \\
\text { perception of their child } \\
\text { as more vulnerable, } \\
\text { with ED mothers } \\
\text { tending towards greater } \\
\text { pleasure. }\end{array}$ & $\begin{array}{l}\text { The absence of a genetic } \\
\text { link between a parent } \\
\text { and a child does not } \\
\text { necessarily jeopardize } \\
\text { the development of a } \\
\text { positive relationship } \\
\text { between them. }\end{array}$ \\
\hline
\end{tabular}

\section{Conclusion}

A thorough read-up in 10 studies has been made to understand and be able to compare two same but also different mother types. Sharing or not a genetic link with the embryo, a mother remains a mother when breeding, and child's wellness is her first precedence.

From researches who analyze mothers of 6-18 months old infants, we conclude that mothers missing a genetic bond with their child are often be characterized by low confidence as parents and seem, as a result, to have a shortage in mother-child interactions against their competitors. No other significant differences occurred between those two comparison groups. At the age of 1, 2 and-or 3 years old children's mothers' well-being and psychological adjustment are at both types very alike with only one significant difference been found in one research by present surrogacy mothers less anxious and distressed.

The disclosure factor is also a determinant variable capable to influence ED or surrogacy mothers' feelings and attitude towards the child and therefore its psychological adjustment. One study concludes that mothers who have started the procedure or even have already talked to their child about its origin appeared to be less anxious and depressed and their children more well-adjusted. From the children's point of view, not being gestated by their mother seems to be a bigger problem for them than the genetic bond. Missing a genetic link often seems to bring closer the mother and child and improve their relationship. Likewise, studies showed that mothers of 1 and 7-year-old children who have not decide disclosure experience higher levels of anxiety, depression and have less parent confidence, and their children are often influenced by their mothers' attitudes and have a hard time adjusting.

For marital satisfaction, both family groups did not appear to have any significant difference. At the age of 7 and-or 10 years old children not many differences again have occurred at any variable. Only one study found that 7 years old children share fewer common activities with their mother in NC family's alike ED families.

Taking into account all the above conclusions, ED mothers in comparison to genetically connected mothers (NC or IVF) experience motherhood with some extra worries and feelings. Low parenting confidence and insecurity as a result of the missing genetic link to the embryo and the older age of the mother, add a little more anxiety to the ascendant mother. The thoughts about disclosure and the reaction of the child beget apprehension. At the other end of the spectrum, the 
comparison group of genetic related to the embryo mothers' do not have such worries as commonly they experience motherhood younger and child's origins are not something that needs clarification.

Furthermore, ED and in general mothers after IVF, usually, exaggerate their feelings and in caregiving, with the risk to become overprotected. Struggle and expectation to enter parenthood make the child something very precious for them. They are often dedicated and very affectionate parents as parenthood for them was fully desired. Parenthood can never arise "in accident" alike to natural conception.

As new ART methods will gain their position in the future, further research has to be made about how the adjustment to motherhood is experienced by women without genetic link, in contrast to women genetically connected to their embryo. It is important to continue auditing outcomes and reporting long-term follow-up of mothers, as advances in reproductive techniques, have provided various alternative ways to bear a child.

\section{Compliance with ethical standards}

\section{Disclosure of conflict of interest}

The authors declare that they have no competing interests.

\section{References}

[1] CDC. Assisted Reproductive Technology Fertility Clinic Success Rates Report.

[2] Ilioi EC, Golombok S. Psychological adjustment in adolescents conceived by assisted reproduction techniques: a systematic review. Human Reproduction Update. 2014; 21(1): 84-96.

[3] Kamel RM. Assisted Reproductive Technology after the Birth of Louise Brown. J Reprod Infertil. Jul 2013; 14(3): 96-109.

[4] International Classification of Diseases, 11th Revision (ICD-11) Geneva: WHO. 2018.

[5] Beall SA, DeCherney A. History and challenges surrounding ovarian stimulation in the treatment of infertility. Fertility and Sterility. 2012; 97(4): 795-801.

[6] Glazer ES and Weidman Sterling E. Having Your Baby through Egg Donation. 2nd Edition, London and Philadelphia: Jessica Kingsley Publ. 2013.

[7] Imrie S, Jadva V, Golombok S. Psychological well-being of identity-release egg donation parents with infants. Human Reproduction. 1 Nov 2019; 34(11): 2219-2227.

[8] ESHRE,Copenhagen, Denmark (2020) . ICMART Preliminary World Report. 2016.

[9] Imrie S, Jadva V. The long-term experiences of surrogates: relationships and contact with surrogacy families in genetic and gestational surrogacy arrangements. Reproductive BioMedicine Online. 2014; 29(4): 424-435.

[10] Lindheim SR, Klock SC. Oocyte donation: lessons from the past, directions for the future. Fertility and Sterility. 2018; 110(6): 979-980.

[11] Rachels JA. Report from America: Baby M. Bioethics. 1987; 1(4): 356-365.

[12] Li YJ, Haws KL, Griskevicius V. Parenting Motivation and Consumer Decision-Making. Journal of Consumer Research. 2019; 45(5): 1117-1137.

[13] Chodorow NJ. The reproduction of Mothering Psychoanalysis and Sociology of Gender. Oakland, California: University of California Press. 1999.

[14] Mercer RT. Becoming a Mother versus Maternal Role Attainment. Journal of Nursing Scholarship. 2004; 36(3): 226-232.

[15] Nelson AM. Transition to Motherhood. Journal of Obstetric, Gynecologic \& Neonatal Nursing. 2003; 32(4): 465477.

[16] Moher D, Shamseer L, Clarke M, Ghersi D, Liberati A, Petticrew M, Shekelle P, Stewart LA, Group PRISMA-P. Preferred reporting items for systematic review and meta-analysis protocols (PRISMA-P) 2015 statement. Syst Rev. Jan 2015; 4(1): 1. 
[17] Imrie S, Jadva V, Fishel S, Golombok S. Families Created by Egg Donation: Parent-Child Relationship Quality in Infancy. Child Development. 2019; 90(4): 1333-1349.

[18] Blake L, Jadva V, Golombok S. Parent psychological adjustment, donor conception and disclosure: a follow-up over 10 years. Human Reproduction. 2014; 29(11): 2487-2496.

[19] Golombok S, Blake L, Casey P, Roman G, Jadva V. Children born through reproductive donation: a longitudinal study of psychological adjustment. Journal of Child Psychology and Psychiatry. 2013; 54(6): 653-660.

[20] Golombok S, Jadva V, Lycett E, Murray C, MacCallum F. Families created by gamete donation: follow-up at age 2. Human Reproduction. 2005; 20(1): 286-293.

[21] Golombok S, MacCallum F, Murray C, Lycett E, Jadva V. Surrogacy families: parental functioning, parent-child relationships and children's psychological development at age 2. Journal of Child Psychology and Psychiatry. 2006; 47(2): 213-222.

[22] Blake L, Casey P, Jadva V, Golombok S. "I was quite amazed": Donor Conception and Parent-Child Relationships from the Child's Perspective. Children \& Society. 2014; 28(6): 425-437.

[23] Golombok S, Murray C, Jadva V, MacCallum F, Lycett E. Families Created Through Surrogacy Arrangements: Parent-Child Relationships in the 1st Year of Life. Developmental Psychology. 2004; 40(3): 400-411.

[24] Golombok S, Murray C, Javda V, Lycett E, MacCallum F, Rust J. Non-genetic and non-gestational parenthood: consequences for parent-child relationships and the psychological well-being of mothers, fathers and children at age 3. Human Reproduction. 2006; 21(7): 1918-1924.

[25] Golombok S, Readings J, Blake L, Casey P, Mellish L, Marks A, Jadva V. Children conceived by gamete donation: Psychological adjustment and mother-child relationships at age 7. Journal of Family Psychology. 2011; 25(2): 230-239. 